\title{
Time Frame Text
}

National Cancer Institute

\section{Source}

National Cancer Institute. Time Frame Text. NCI Thesaurus. Code C93693.

A character string that identifies time point(s) at which an event or activity occurrs. 